\title{
Neurofilament light chain levels in MS
}

\section{At the doorstep of clinical application}

Neurol Neuroimmunol Neuroinflamm September 2019 vol. 6 no. 5 e601. doi:10.1212/NXI.0000000000000601

In addition to the mysteries and autobiographies that some of you may be packing for a late summer vacation or long weekend, consider including the current issue of N2. Each article has a plot that will leave you on edge, and here, I will introduce some of them. It is well known that the presentation of MS is diverse, with some patients presenting early with very mild disease and others presenting late with extensive damage from silent disease. Until now, the best biomarker of disease activity and treatment effects has been the MRI. However, MRI has several limitations, including availability, cost, interscan variability, limited sensitivity for predicting disease progression, and the need to include the spinal cord for comprehensive assessment. Serum neurofilament light chain (NfL), a neuroaxonal intermediate protein, is a promising biomarker candidate. Elevated serum levels of NfL in patients with MS substantially decrease when the disease is controlled by treatment, and this may have prognostic value. In this issue of N2, Thebault et al. ${ }^{1}$ assessed the NfL levels in serum and CSF, along with MRI and clinical measures, in patients with MS at baseline and 1 and 3 years after immunoablative chemotherapy followed by autologous hematopoietic stem cell transplantation (IAHSCT). The authors found that at baseline, NfL levels in patients with MS were significantly elevated compared with those of controls and that after IAHSCT, NfL levels in patients with MS decreased and became not significantly different from the levels of controls. These and other findings related to the associations between NfL levels and clinical and MRI outcomes are discussed by the authors and in an editorial comment by Leppert and Kuhle ${ }^{2}$ suggesting that blood NfL testing is at the doorstep of clinical application.

Moving to another study in which NfL levels are also featured, Engel et al. ${ }^{3}$ investigated the incremental value of adding multiple disease activity biomarkers (CD20+/CD14+ ratio, NfL levels, and chitinase 3-like protein 1 [CHI3L1] levels) in CSF and serum for distinguishing MRIbased benign from aggressive MS in early disease course. The study included 93 patients with clinically isolated syndrome or early MS and 145 controls with inflammatory and noninflammatory brain diseases. The CSF CD20+/CD14+ ratios and NfL levels, but not the levels of CHI3L1, in serum and CSF were significantly different between high and low MRI-severity groups. The findings suggest that combining biomarkers of intrathecal B-cell accumulation and axonal damage (NfL levels) helps to distinguish MRI-based benign from aggressive disease at an early stage and could contribute to more personalized treatment decisions by identifying patients with a higher risk of disease progression.

In another study, Diebold et al. ${ }^{4}$ investigated whether disease-modifying treatments put patients with MS at risk of acute or chronic hepatitis $\mathrm{E}$ virus (HEV) infection. In this study, almost 1,100 patients with MS were followed and those who developed unexplained liver enzyme elevations were screened for HEV infection. Over a 2-year period, 4 cases of HEV infections were identified, of whom 2 had severe infections with acute liver failure, 1 was asymptomatic, and 1 had extrahepatic manifestations. The infection was not associated with any clinical or radiologic signs 
of disease activity, and none of the 4 patients developed chronic $\mathrm{HEV}$ infection. Based on available epidemiologic data, the authors conclude that disease-modifying therapies do not increase the overall risk of HEV infections in patients with MS.

The study by Hagen et al. ${ }^{5}$ investigated whether there was an association between the development of systemic inflammatory response syndrome (SIRS) and long-term outcome in patients with intracerebral hemorrhage (ICH). Consecutive patients with spontaneous ICH were screened for the presence of SIRS during the acute hospitalization. Patients with ICH and a systemic infection were excluded, focusing the study on the impact of noninfectious SIRS. Of the 780 patients included in the study, $21.8 \%$ developed noninfectious SIRS. Compared with patients who did not develop SIRS (and did not have systemic infection), patients with SIRS had significantly greater stroke severity, less favorable ICH characteristics (e.g., larger ICH volume and more intraventricular hemorrhage), and poorer functional outcome after 3 and 12 months. Preexisting liver dysfunction and hematoma enlargement were identified as potentially contributing to the SIRS. If confirmed, this study suggests that systemic inflammation may be an independent predictor of $\mathrm{ICH}$ outcome and therefore a potential target for interventions.

In another study, Piquet et al. ${ }^{6}$ describe the clinical features of 17 patients with glycine receptor (GlyR) antibodies identified in 2 academic centers during a period of 2 years. Twelve patients (71\%) developed symptoms of stiff-person syndrome, and $8(47 \%)$ had cerebellar or parkinsonian features. Notably, 10 patients (59\%) presented with various visual changes such as visual snow, spider web-like images, palinopsia, photophobia, visual hallucinations, and intermittent diplopia. Autoimmune seizures occurred in 3 patients, 2 of them associated with status epilepticus, and all accompanied by psychiatric symptoms. The authors suggest considering GlyR autoimmunity in patients with stiff-person syndrome who additionally have visual symptoms or parkinsonian features. However, as acknowledged by the authors, the study has some limitations; 9 patients (53\%) had glutamic acid decarboxylase (GAD) antibodies, 3 (18\%) low levels of N-type or P/Q-type voltage-gated calcium channel antibodies, and 1 thyroid peroxidase antibodies, which complicate the interpretation of some of the findings. This and the fact that immunologic studies were not performed in CSF may suggest an expansion of anti-GlyR phenotypes, when in fact some of the symptoms could be potentially related to other mechanisms.

In addition to these studies, the September issue of N2 contains other interesting articles that I hope will catch your attention.

\section{Study funding}

No targeted funding reported.

\section{Disclosure}

J. Dalmau holds patents for the use of Ma2, NMDAR, GABABR, GABAAR, DPPX, and IgLON5 as autoantibody tests and receives royalties from the use of these tests. Go to Neurology.org/NN for full disclosures.

\section{References}

1. Thebault $\mathrm{S}$, Tessier $\mathrm{D}$, Lee $\mathrm{H}$, et al. High serum neurofilament light chain normalises after haematopoietic stem cell transplant for MS. Neurol Neuroimmunol Neuorinflamm 2019;6:e598. doi.org/10.1212/NXI.0000000000000598.

2. Leppert D, Kuhle J. Blood Neurofilament light chain at the doorstep of clinical application. Neurol Neuroimmunol Neuorinflamm 2019;6:e599. doi.org/10.1212/NXI. 0000000000000599.

3. Engel S, Friedrich M, Muthuraman M, et al. Intrathecal B cell accumulation and axonal damage distinguish MRI-based benign from aggressive onset in MS. Neurol Neuroimmunol Neuorinflamm 2019;6:e595. doi.org/10.1212/NXI.0000000000000595.

4. Diebold M, Fischer-Barnicol B, Tsagkas C, et al. Hepatitis E Virus infections in multiple sclerosis patients on oral disease modifying treatment. Neurol Neuroimmunol Neuorinflamm 2019;6:e594. doi.org/10.1212/NXI.0000000000000594.

5. Hagen M, Sembill JA, Spruegel MI, et al. Systemic inflammatory response syndrome and long-term outcome after intracerebral hemorrhage. Neurol Neuroimmunol Neuorinflamm 2019;6:e588. doi.org/10.1212/NXI.0000000000000588.

6. Piquet AL, Khan M, Warner J, et al. Novel clinical features of glycine receptor antibody syndrome: a series of seventeen cases. Neurol Neuroimmunol Neuorinflamm 2019;6:e592. doi.org/10.1212/NXI.0000000000000592. 


\section{Neurology \\ Neuroimmunology \& Neuroinflammation}

Neurofilament light chain levels in MS: At the doorstep of clinical application Josep Dalmau

Neurol Neuroimmunol Neuroinflamm 2019;6;

DOI 10.1212/NXI.0000000000000601

This information is current as of August 16, 2019

Updated Information \&

Services

References

Permissions \& Licensing

Reprints including high resolution figures, can be found at:

http://nn.neurology.org/content/6/5/e601.full.html

This article cites 6 articles, 0 of which you can access for free at: http://nn.neurology.org/content/6/5/e601.full.html\#\#ref-list-1

Information about reproducing this article in parts (figures,tables) or in its entirety can be found online at:

http://nn.neurology.org/misc/about.xhtml\#permissions

Information about ordering reprints can be found online: http://nn.neurology.org/misc/addir.xhtml\#reprintsus

Neurol Neuroimmunol Neuroinflamm is an official journal of the American Academy of Neurology.

Published since April 2014, it is an open-access, online-only, continuous publication journal. Copyright

Copyright (C) 2019 The Author(s). Published by Wolters Kluwer Health, Inc. on behalf of the American

Academy of Neurology.. All rights reserved. Online ISSN: 2332-7812.

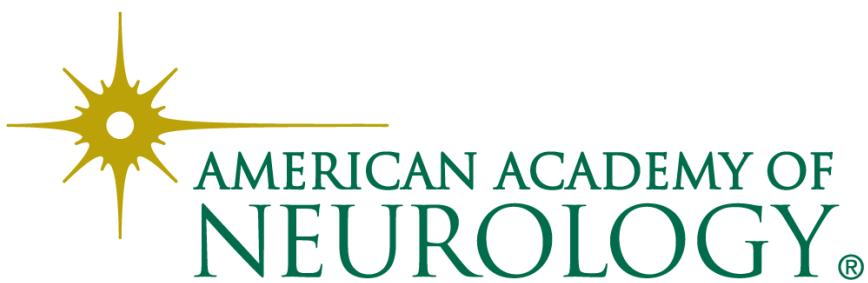

